УДК 502:504

\title{
Ангеліна ЧУГАЙ
}

доктор технічних наук, дочент, декан природоохоронного факультету, Одеський державний екологічний університет, вул. Львівська, 15, м. Одеса, Україна, 65016

ORCID: 0000-0002-8091-8430

\section{Галина БОРОВСЬКА}

кандидат географічних наук, доиент кафедри метеорології та кліматології, Одеський держсавний екологічний університет, вул. Львівська, 15, м. Одеса, Україна, 65016

ORCID: 0000-0001-9649-7661

\section{Данило ТИМОШЕНКО}

магістрант кафедри екології та охорони довкілля, Одеський державний екологічний університет, вул. Львівська, 15, м. Одеса, Україна, 65016

Бібліографічний опис статті: Чугай, А., Боровська, Г., Тимошенко, Д. (2021). Оцінка техногенного впливу на повітряний басейн північних регіонів України. Проблеми хімії та сталого розви$m \kappa y$, 4, 68-73, doi: https://doi.org/10.32782/pcsd-2021-4-10

\section{ОЦІНКА ТЕХНОГЕННОГО ВПЛИВУ НА ПОВІТРЯНИЙ БАСЕЙН ПІВНІЧНИХ РЕГІОНІВ УКРАЇНИ}

Проблема забруднення і техногенного впливу на повітряний басейн залишається особливо гострою для регіонів України. У роботі здійснено оцінку і аналіз техногенного впливу на повітряний басейн окремих північних областей Украӥни (Житомирська, Чернігівська і Сумська). За даними Національної доповіді, обсяги викидів забруднювальних речовин у циих регіонах від стаціонарних джерел є незначними (порівняно з іншими регіонами). Переважними джерелами викидів залишаються пересувні. Як вихідні дані використані матеріали Регіональних доповідей про викиди забруднювальних речовин в атмосферне повітря за 2015-2020 рр. Для оиінки техногенного

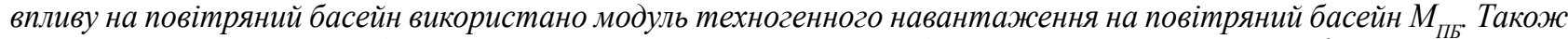
проаналізовано вплив виробничої діяльності на стан повітряного басейну із застосуванням коефічієнта екологіч-

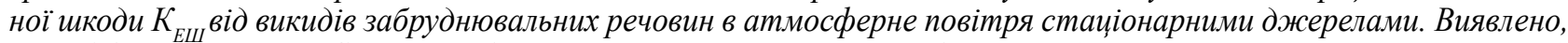
щุо в Житомирській і Сумській областях показники загального обсягу викидів є майже порівняними за період дослідження. У Чернігівській області з 2017 р. спостерігається суттєве зменшення викидів забруднювальних речовин. Внесок пересувних джерел забруднення максимальним є у Житомирській області, мінімальним - у Чернігівській. Рівень техногенного навантаження за значенням $M_{\Pi ь} \epsilon$ максимальним у Сумській області. При максимальних значеннях викидів забруднювальних речовин у 2015-2016 рр. у Чернігівській області рівень техногенного

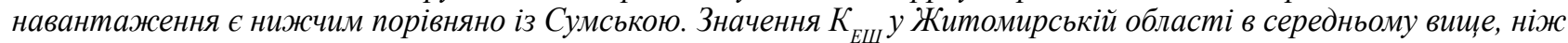
y Чернігівській. Відзначено суттєве зменшення $K_{\text {Еш }}$ у Чернісівській області, шчо свідчить про поліпшення умов екологічної безпеки від виробничої діяльності регіону. Отримані результати можна уточнювати з урахуванням однакового переліку забруднювальних речовин, які враховуються при розрахунках.

Ключові слова: техногенний вплив, повітряний басейн, північні регіони.

\section{Angelina CHUGAI}

Doctor of Science (Technical), Associate Professor, Dean of Nature Protection Faculty, Odesa State Environmental University, 15 Lvivska str., Odesa, Ukraine, 65106

ORCID: 0000-0002-8091-8430

\section{Halyna BOROVSKA}

PhD in Geography, Associate Professor at the Department of Meteorology and Climatology, Odesa State Environmental University, 15 Lvivska str., Odesa, Ukraine, 65106

ORCID: 0000-0001-9649-7661 


\title{
Danylo TYMOSHENKO
}

Undergraduate at the Department of Environmental Science and Environmental Protection, Odesa State Environmental University, 15 Lvivska str., Odesa, Ukraine, 65106

To cite this article: Chugai, A., Borovska, H., Tymoshenko, D. (2021). Otsinka tekhnohennoho vplyvu na povitrianyi basein pivnichnykh rehioniv Ukrainy [Assessment of technogenic impact on the air basin of the Ukraine northern regions]. Problems of Chemistry and Sustainable Development, 4, 68-73, doi: https://doi.org/10.32782/pcsd-2021-4-10

\section{ASSESSMENT OF TECHNOGENIC IMPACT ON THE AIR BASIN OF THE UKRAINE NORTHERN REGIONS}

\begin{abstract}
The problem of pollution and technogenic impact on the air basin remains particularly acute for the regions of Ukraine. The paper evaluates and analyzes the technogenic impact on the air basin of some northern regions of Ukraine (Zhytomyr, Chernihiv and Sumy). According to the National Report, pollutant emissions in these regions from stationary sources are insignificant compared to other regions. But the predominant sources of emissions remain mobile. The materials of the Regional Reports on pollutant emissions for 2015-2020 were used as initial data. The module of technogenic load $M_{A B}$ on the air pool was used to assess. The impact of production activities on the state of the air basin was also analyzed using the coefficient of environmental damage $C_{E D}$ from emissions of pollutants to the atmosphere by stationary sources. It was found that in Zhytomyr and Sumy regions the indicators of total emissions are almost comparable for the study period. In the Chernihiv region since 2017 there has been a significant reduction in emissions of pollutants. The contribution of mobile sources of pollution is maximum in Zhytomyr region, minimum - in Chernihiv region. The level of technogenic load according to the $M_{A B}$ is the maximum in Sumy region. With the maximum values of pollutant emissions in 2015-2016 in the Chernihiv region, the level of technogenic load is lower compared to Sumy region. The value of $C_{E D}$ in Zhytomyr region is on average higher than in Chernihiv region. There has been a significant decrease in the number of $C_{E D}$ registers in the Chernihiv region, which indicates an improvement in environmental safety from the production activities of the region. The obtained results can be specified taking into account the same list of pollutants that are taken into account in the calculations.
\end{abstract}

Key words: technogenic impact, air basin, northern regions.

Вступ. Проблема забруднення і техногенного впливу на повітряний басейн залишається особливо гострою для регіонів України. У великих промислово-міських агломераціях рівень забруднення формується залежно від виду виробництва і рівнів технологій, що застосовуються. Крім того, у більшості міст України перше місце серед джерел забруднення повітря міцно утримується автомобільним транспортом (до $80 \%$ і більше від загального обсягу викидів).

Метою статті $є$ оцінка й аналіз техногенного впливу на повітряний басейн окремих північних областей України (Житомирська, Чернігівська і Сумська).

До основних джерел забруднення атмосфери Житомирської області належать теплове та енергетичне устаткування, промислові підприємства, добувна та обробна галузь господарства, а також усі види транспорту (Регіональна доповідь про стан навколишнього природного середовища Житомирської області, 2020). Переважним забруднювачем атмосферного повітря є пересувні джерела (більше $80 \%$ викидів в окремі роки).
Сумська область характеризується розвиненим промисловим потенціалом i, за окремими даними, за рівнем техногенного навантаження посідає місце в першому десятку регіонів України (Сумська область, 2021).

Основу економіки Чернігівської області становлять промисловість і сільське господарство. Пріоритетними галузями промисловості є харчова, целюлозно-паперова, паливна, машинобудівна, а також хімічна, легка і деревообробна (Доповідь про стан навколишнього природного середовища в Чернігівській області, 2019).

За даними Національної доповіді (Національна доповідь, 2019), обсяги викидів забруднювальних речовин (далі - ЗР) у цих регіонах від стаціонарних джерел є незначними (порівняно з іншими регіонами, як-от Вінницька, Дніпропетровська, Запорізька та ін. області). Але згідно злітературними джерелами переважними джерелами викидів залишаються пересувні.

Матеріали і методи досліджень. Як вихідні дані в роботі використані матеріали Регіональних доповідей про викиди ЗР в атмосферне повітря від стаціонарних і пересувних джерел забруднення за 2015-2020 pp. 
Для оцінки техногенного навантаження на повітряний басейн регіонів дослідження використано модуль техногенного навантаження на повітряний басейн $M_{\Pi Б}$, запропонований у роботі (Чугай, 2020). Цей показник визначається як відношення обсягу викидів ЗР від стаціонарних і пересувних джерел за 1 рік (тис. т) до площі адміністративного регіону або області. Визначення $M_{\text {пь }}$ передбачає підсумовування обсягів викидів 3Р з указаних джерел.

Також проаналізовано вплив виробничої діяльності на стан повітряного басейну. Із цією метою застосовано коефіцієнт екологічної шкоди $K_{E \amalg}$ від викидів ЗР в атмосферне повітря стаціонарними джерелами. У загальному вигляді (згідно з методикою (Радевич, Ночовна $\&$ Самбурська, 2017)) цей показник визначається за формулою:

$$
K_{E \amalg}=\sqrt[n]{\frac{B_{1}}{\Gamma Д K_{1}} \cdot \frac{B_{2}}{\Gamma Д K_{2}} \cdot \ldots \cdot \frac{B_{n}}{\Gamma Д K_{n}}},
$$

де $B_{1}, B_{2}, \ldots, B_{n}-$ фактичні обсяги викидів $i$-ої ЗР в атмосферне повітря та/або скидів у водні об'єкти, розміщення відходів, утворення радіоактивних відходів (Радевич, Ночовна \& Самбурська, 2017).

У роботі враховано лише обсяги викидів ЗР від стаціонарних джерел забруднення. Чим нижчим $\epsilon$ значення цього показника, тим вищим є рівень екологічної безпеки.
Результати дослідження та їх обговорення. Проаналізовано динаміку викидів ЗР від стаціонарних і пересувних джерел у досліджуваних регіонах за 2015-2020 pp. (рис. 1) за даними Регіональних доповідей (Регіональна доповідь про стан навколишнього природного середовища Житомирської області, 2020; Доповідь про стан навколишнього природного середовища в Чернігівській області, 2019; Регіональна доповідь про стан навколишнього природного середовища Житомирської області, 2021; Доповідь про стан навколишнього природного середовища в Сумській області, 2020; Регіональна доповідь про стан навколишнього природного середовища в Сумській області, 2021; Доповідь про стан навколишнього природного середовища в Чернігівській області, 2021). Слід зазначити, що дані про обсяги викидів від пересувних джерел у Сумській і Чернігівській області з 2016 р. відсутні. Тому з урахуванням відомостей про обсяги викидів у попередні роки ці дані були нами проінтерпольовані.

Із рис. 1. видно, що в Житомирській і Сумській областях показники загального обсягу викидів є майже порівняними за період дослідження. У Чернігівській області у 2015-2016 pp. загальний обсяг викидів був максимальним, із 2017 р. спостерігається зменшення показників. Унесок пересувних джерел забруднення серед трьох регіонів максимальним є у Житомирській області, мінімальним - у Чернігівській.

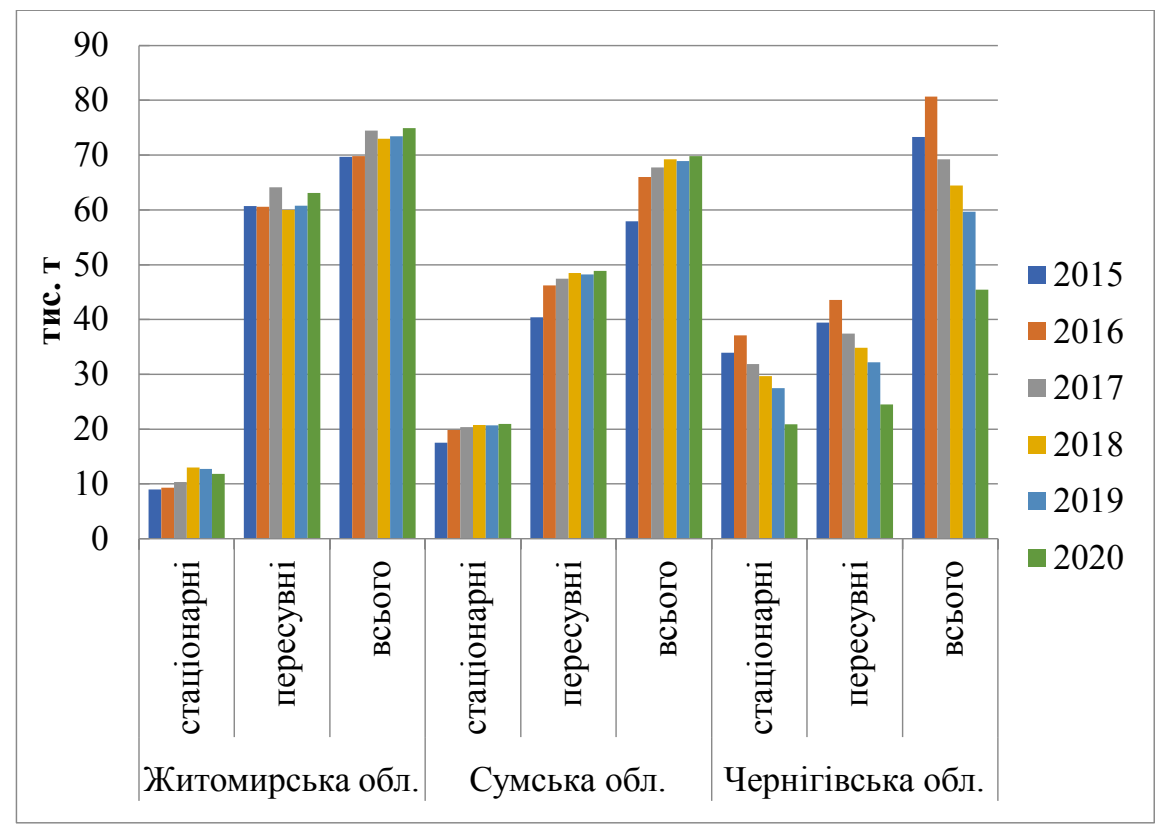

Рис. 1. Викиди ЗР в атмосферне повітря північних регіонів України 


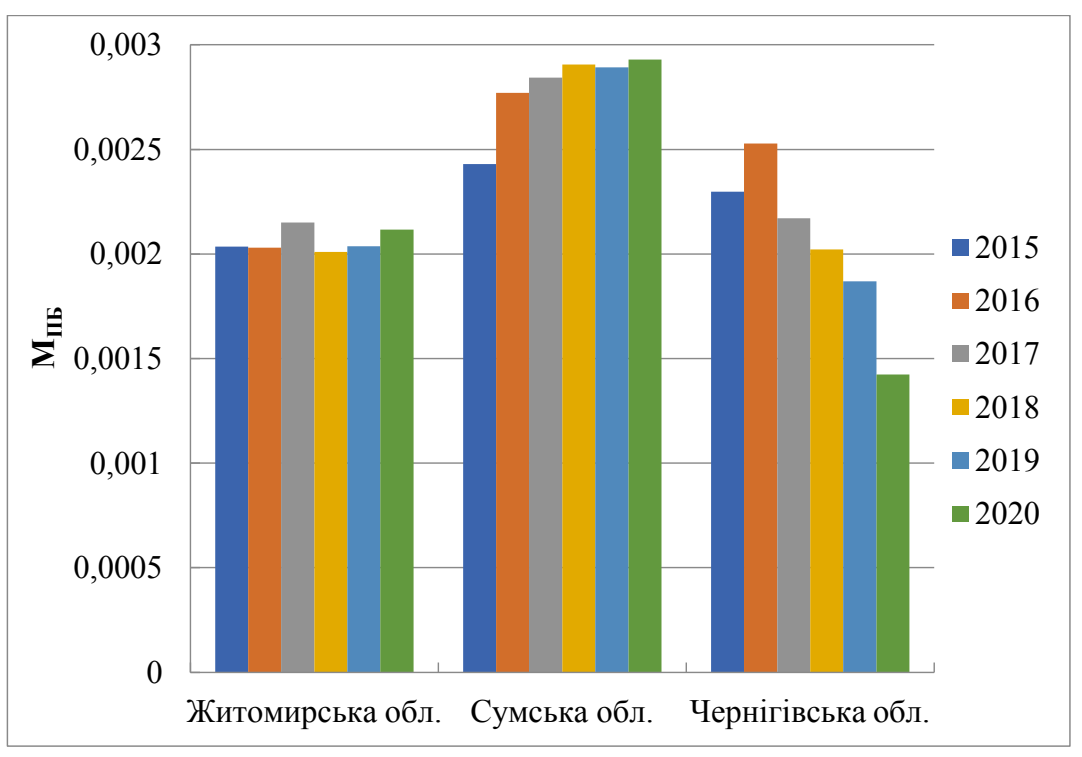

Рис. 2. Значення $M_{I 5}$ північних регіонів України y 2015-2020 pp.

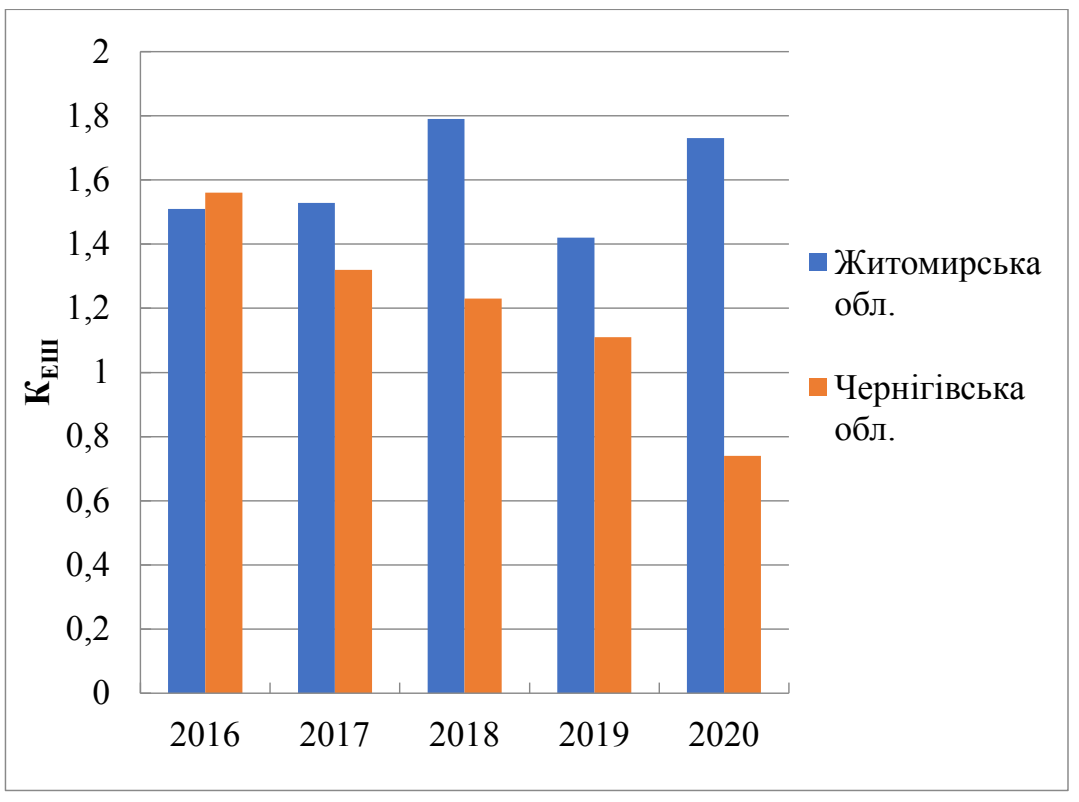

Рис. 3. Значення $\boldsymbol{K}_{E \amalg}$ від стаціонарних джерел забруднення (Житомирська і Чернігівська області)

Результати оцінки техногенного навантаження на повітряний басейн північних регіонів України наведено на рис. 2. Так, рівень техногенного навантаження $є$ максимальним у Сумській області. Як зазначено вище, обсяги викидів у Сумській і Житомирській областях майже однакові. У разі максимальних значень викидів ЗР у 2015-2016 pp. у Чернігівській області рівень техногенного навантаження $є$ нижчим порівняно із Сумською.

Оцінку впливу виробничої діяльності на стан повітряного басейну проведено для двох облас- тей - Житомирської і Чернігівської. Результати розрахунків за період 2016-2020 pр. наведено на рис. 3. Зазначимо, що в процесі розрахунків для Житомирської області враховувалось 5 речовин ( $\mathrm{CO}, \mathrm{SO}_{2}, \mathrm{NO}_{2}, \mathrm{NO}, \mathrm{NH}_{3}$ ), для Чернігівської - 4 (CO, $\mathrm{SO}_{2}, \mathrm{NO}_{2}$, пил).

Як видно з рис. 3 , значення показника в Житомирській області в середньому є дещо вищим, ніж у Чернігівській. Слід також указати на суттєве зменшення $K_{E \amalg}$ у Чернігівській області, що свідчить про поліпшення умов екологічної безпеки від виробничої діяльності регіону. 
Вище зазначено, що обсяги викидів ЗР від стаціонарних джерел у Чернігівській області майже втричі перевищують відповідні показники у Житомирській. Уважаємо, що отримані результати можна пояснити врахуванням різної кількості ЗР під час визначення $K_{E \amalg}$, що є певним недоліком методики в разі застосування для порівняльної оцінки в регіонах України.

Висновки. У роботі оцінено техногенний вплив на повітряний басейн окремих північних регіонів України. Отримані результати дозволяють зробити такі висновки:

У Житомирській і Сумській областях показники загального обсягу викидів $\epsilon$ майже порівняними за період 2015-2020 pp. У Чернігівській області у 2015-2016 pp. загальний обсяг викидів був максимальним, із 2017 р. спостері- гається зменшення викидів ЗР. Внесок пересувних джерел забруднення серед трьох регіонів максимальним є у Житомирській області, мінімальним - у Чернігівській.

Рівень техногенного навантаження за значенням $M_{\Pi ь} \in$ максимальним у Сумській області. У разі максимальних значень викидів 3Р у 2015-2016 pp. у Чернігівській області рівень техногенного навантаження $є$ нижчим (порівняно із Сумською).

Значення $K_{E Ш ~}$ у Житомирській області в середньому є дещо вищим, ніж у Чернігівській. Виявлено суттєве зменшення $K_{E \amalg}$ у Чернігівській області, що свідчить про поліпшення умов екологічної безпеки від виробничої діяльності регіону. Отримані результати можна уточнювати з урахуванням однакового переліку 3Р, які враховуються в процесі розрахунків.

\section{ЛIТЕРАТУРА:}

1. Регіональна доповідь про стан навколишнього природного середовища Житомирської області у 2019 році. Житомир, 2020. 218 c.

2. Сумська область. URL: http://rada.com.ua/ukr/RegionsPotential/Sumy/ (дата звернення: 25.04.2021).

3. Доповідь про стан навколишнього природного середовища в Чернігівській області за 2018 рік. Чернігів, 2019. $235 \mathrm{c}$.

4. Національна доповідь про стан навколишнього природного середовища в Україні у 2018 р. Київ, 2019. 483 с.

5. Чугай А.В. Науково-методологічні засади комплексної оцінки техногенного навантаження на поліфунціональні території (на прикладі Північно-Західного Причорномор'я) : дис. ... д-ра т. наук : 21.06.01 / Київський. нац. ун-т будівництва і архітектури. Київ, 2020. 368 с.

6. Радевич Т.В., Ночовна Ю.О., Самбурська Н.І. Моделювання інтегрального показника загального рівня екологічної безпеки підприємства. Економічний аналіз. 2017. Т. 27. № 2. С. 182-191.

7. Регіональна доповідь про стан навколишнього природного середовища Житомирської області у 2020 році. Житомир, 2021. 187 с.

8. Доповідь про стан навколишнього природного середовища в Сумській області у 2019 році. Суми, 2020. $202 \mathrm{c}$.

9. Регіональна доповідь про стан навколишнього природного середовища в Сумській області у 2020 році. Суми, 2021. $191 \mathrm{c.}$

10. Доповідь про стан навколишнього природного середовища в Чернігівській області у 2020 році. Чернігів, 2021. $255 \mathrm{c}$.

\section{REFERENCES:}

11. Rehionalna dopovid pro stan navkolyshnoho pryrodnoho seredovyshcha Zhytomyrskoi oblasti u 2019 rotsi. [Regional report on the state of the environment of Zhytomyr region in 2019] (2020). Zhytomyr. [in Ukrainian]

12. Sumska oblast. [Sumy region]. Retrieved from: http://rada.com.ua/ukr/RegionsPotential/Sumy/. [in Ukrainian]

13. Dopovid pro stan navkolyshnoho pryrodnoho seredovyshcha v Chernihivskii oblasti za 2018 rik. [Report on the state of the environment of Chernihiv region in 2018] (2019). Chernihiv. [in Ukrainian]

14. Natsionalna dopovid pro stan navkolyshnoho pryrodnoho seredovyshcha v Ukraini u $2018 \mathrm{r}$. [National report on the state of the environment in Ukraine in 2018] (2019). Kyiv. [in Ukrainian]

15. Chugai A.V. (2020). Naukovo-metodolohichni zasady kompleksnoi otsinky tekhnohennoho navantazhennia na polifuntsionalni terytorii (na prykladi Pivnichno-Zakhidnoho Prychornomoria) [Scientific and methodological methods of a comprehensive assessment of technogenic loading on multifunctional territories (on the example of the North-Western Black Sea region)]: dys. ... d-ra t. nauk: 21.06.01. Kyiv. [in Ukrainian]

16. Radevych, T.V., Nochovna, Yu.O., Samburska, N.I. (2017). Modeliuvannia intehralnoho pokaznyka zahalnoho rivnia ekolohichnoi bezpeky pidpryiemstva. [Modeling of the integrated indicator of the general level of ecological safety of the enterprise]. Ekonomichnyi analiz - Economic analysis. 27, 2, 182 - 191. [in Ukrainian] 
17. Rehionalna dopovid pro stan navkolyshnoho pryrodnoho seredovyshcha Zhytomyrskoi oblasti u 2020 rotsi. [Regional report on the state of the environment of Zhytomyr region in 2020] (2021). Zhytomyr. [in Ukrainian]

18. Dopovid pro stan navkolyshnoho pryrodnoho seredovyshcha v Sumskii oblasti u 2019 rotsi. [Report on the state of the environment of Sumy region in 2019] (2020). Sumy. [in Ukrainian]

19. Rehionalna dopovid pro stan navkolyshnoho pryrodnoho seredovyshcha v Sumskii oblasti u 2020 rotsi. [Regional report on the state of the environment of Sumy region in 2020] (2021). Sumy. [in Ukrainian]

20. Dopovid pro stan navkolyshnoho pryrodnoho seredovyshcha v Chernihivskii oblasti u 2020 rotsi. [Report on the state of the environment of Chernihiv region in 2020] (2021). Chernihiv. [in Ukrainian] 